\title{
Etnopedagogik dalam Kaulinan Oray-Orayan
}

\author{
RYAN DWI PUSPITA \\ Prodi Pendidikan Guru Sekolah Dasar, Sekolah Tinggi Keguruan Ilmu Pendidikan \\ Universitas Sebelas April Sumedang \\ Email: dwiryan531@gmail.com
}

\begin{abstract}
The purpose of this study is to analyze the values of education contained in the Kaulinan Barudak Sundanese namely, oray. It is a form of children's play that lives and develops in West Java, especially in Cikondang Village, Karanglayung Village, Conggeang District, Sumedang District. This study uses a descriptive analytical method with a qualitative approach. The results of this study are in the kaulinan, oray the people contain values, namely: fertilizing the nature of togetherness, sportsmanship, creativity or love of nature and the environment. Kaulinan has not had pedagogical functions and recreational functions. The type and form of kaulinan orayorayan are very simple, but indirectly contain meaning that is very useful especially for fertilizing the mental attitude of children.
\end{abstract}

Keywords: Kaulinan, Barudak, Oray-orayan, Playing, Games.

\begin{abstract}
Abstrak
Tujuan dari penelitian ini adalah menganalisis nilai-nilai pendidikan yang terkandung dalam kaulinan barudak Sunda yaitu, oray-orayan. la merupakan bentuk permainan anak-anak yang hidup dan berkembang di Daerah Jawa Barat khususnya di Kampung Cikondang Desa Karanglayung Kecamatan Conggeang Kabupaten Sumedang. Penelitian ini menggunakan metode deskriptif analitik dengan pendekatan kualitatif. Hasil dari penelitian ini adalah dalam kaulinan barudak oray-orayan terkandung nilai yaitu: pemupukan sifat kebersamaan, sportifitas, kreativitas ataupun kecintaan terhadap alam dan lingkungan. Kaulinan barudak oray-orayan juga memiliki fungsi pedagogis dan fungsi rekreatif. Jenis dan bentuk kaulinan oray-orayan sangat sederhana, tetapi secara tidak langsung mengandung makna yang sangat berguna terutama bagi pemupukan sikap mental anak-anak.
\end{abstract}

Kata Kunci: Kaulinan, Barudak, Oray-orayan, Bermain, Permainan. 


\section{Pendahuluan}

Seiring dengan perkembangan zaman, beragam permainan anak-anak dari mulai permainan tradisional sampai permainan modern. Di era modern seperti ini sangat disayangkan sepertinya permainan tradisional anak-anak mulai tergerus dengan hadirnya permainan canggih berbasis teknologi. Sebenarnya pada saat ini kaulinan barudak masih berlangsung, seperti halnya, oray-orayan, tetapi pelaksanaannya hanya dilakukan ditempat-tempat tertentu misalnya di pedesaan, pada sekolah tertentu atau pada komunitas tertentu padahal dalam kaulinan barudak itu secara langsung mengajarkan nilai-nilai yang sangat mendukung untuk perkembangan anak.

Sebagai pendidik yang baik, kita harus peka terhadap situasi dan kondisi pendidikan. Alangkah baiknya apabila kita menggali kearifan lokal yang berada pada masyarakat sekitar kita khususnya budaya sunda, salah satu contohnya budaya kaulinan barudak yang ada pada masyarakat Sunda. Apabila dikaji secara lebih mendalam tentang kaulinan barudak yang ada pada masyarakat Sunda, maka kemungkinan besar akan ditemukan kandungan nilai-nilai pendidikan yang dapat diterapkan pada pembelajaran di Sekolah Dasar.

Jika dimaknai kaulinan barudak sama halnya dengan permainan dan kegiatannya disebut bermain. Bermain merupakan kegiatan yang sangat penting pada kehidupan anak. Karena pada dasarnya bermain dapat melatih setiap anak yang bermain melalui aturan, kesepakatan dan sistem (Alif,2012) dan wajib patuh pada setiap peraturan dalam permainan tersebut. Anak-anak dapat belajar mengenal diri dan lingkungannya melalui bermain. Mereka akan mendapatkan berbagai pengalaman dan kesenangan dari kegiatan bermain tersebut. Anak-anak sebagai generasi penerus yang berpotensi diharapkan dapat membangun bangsa dan negara di masa yang akan datang. Anak-anak harus dipupuk dengan nilai-nilai yang baik sejak dini.
Untuk melestarikan nilai kaulinan barudak sebagai salah satu permainan tradisional dan sebagai kekayaaan kebudayaan Indonesia tentunya tidak bisa mengandalkan anak-anak tetapi perlu campur tangan banyak pihak. Dalam hal ini, orangtua dan guru di lingkungan sekolah memegang peranan penting untuk menyampaikan, menjelaskan,dan memainkan tradisi Sunda dan mengkaji nilai-nilai pendidikan yang dapat diterapkan pada pembelajaran di sekolah ataupun di lingkungan keluarga. Permainan adalah bagian dari kebudayaan masyarakat, karena bermain tidak hanya berfungsi untuk bersenang-senang tetapi sebagai sarana sosialisasi nilai-nilai atau norma dalam masyarakat, khususnya masyarakat di Tatar Sunda. Penulis berpendapat bermain identik dengan anak-anak, yang memiliki kemampuan daya pikir yang sangat kuat, sehingga secara tidak langsung sosialisasi nilainilai pendidikan ini akan mudah dicerna oleh anak-anak yang memainkan kaulinan barudak ini.

Meninjau studi modern tentang bermain yang ditelusuri dan dipublikasikan oleh sejarawan Belanda yaitu Johan Huizinga dalam bukunya "Homo Ludens" (1938). Huizinga menggambarkan bermain sebagai dan kegiatan yang berarti, dilakukan untuk kepentingan diri sendiri, spasial dan temporal dan dipisahkan dari persyaratan kehidupan praktis, dan terikat oleh sistem yang mandiri dan aturan yang benarbenar dipegang. Titik awal filosofis studi Huizinga adalah pengamatan bahwa, di mana ada bermain, ada juga makna. Bermain, masuk akal untuk pemain. Pemain sadar dan mengetahui tujuan permainan, peralatan, dan aturan. Bahkan bentuk yang paling primitif bermain menyiratkan beberapa bentuk pemahaman intuitif. Bermain adalah untuk menggambarkan kebermaknaan bagi para pemain. Bermain demikian erat dengan estetika, dalam pengalaman yang tereduksi. Bermain ditinjau dari konteks peradaban, berbicara tentang bermain merupakan hasil dari beberapa proses evolusi, dalam arti bahwa sesuatu yang semula bermain disahkan menjadi 
sesuatu yang tidak lagi bermain dan selanjutnya disebut budaya. Hal ini menjelaskan bahwa budaya muncul dalam bentuk permainan. Huizinga (1949) yang menjelaskan bahwa,

"Play is older than culture, for culture, however inadequately defined, always presupposes human society, and animals have not waited for man to teach them their playing. We can safely assert,even, that human civilization has added no essential feature to the general idea of play".

Dari pendapat Huizinga di atas dapat dijelaskan bahwa bermain lebih tua dari budaya, berarti bermain itu telah ada sebelum adanya budaya. Untuk budaya sendiri tidak cukup apabila didefinisikan, definisinya selalu mengandaikan masyarakat manusia. Huizinga dengan aman menegaskan bahwa, peradaban manusia telah memberi masukan bahwa adanya fitur penting untuk gambaran umum tentang bermain. Kalau kita kaitkan antara pendapat dari Huizinga dengan lahirnya kaulinan barudak orayorayan terdapat kemungkinan kaulinan orayorayan ini muncul bersama lahirnya budaya Sunda ataupun sebelum adanya budaya Sunda.

Huizinga berpandangan bahwa bermain merupakan aktivitas manusia dalam kehidupan di dunia. Bermain bukan hanya aktivitas fisik tapi merupakan fenomena budaya dan hal itu berarti budaya ditunjang oleh karakter permainan. Budaya mensyaratkan kondisi masyarakat manusia dimana manusia secara proaktif menjalankan berbagai permainan dalam kehidupannya. Bermain tidak sekedar aktivitas fisik dan psikis tapi juga memiliki fungsi yang sangat penting. Dalam permainan, sesuatu yang dimainkan mentransendensi kebutuhan langsung dari kehidupan dan memberi makna pada tindakan. Semua permainan memiliki makna akan sesuatu hal yang berimplikasi pada kualitas non-material dalam kealamiahan benda itu sendiri. Dalam permainan ada kualitas nonmaterial yaitu sisi kesenangan. Eksistensi permainan secara kontinyu terkait dengan supralogis kehidupan manusia.
Permainan merupakan bentuk khusus tindakan manusia yang berfungsi sosial. Huizinga mengambil contoh bahasa sebagai bentuk permainan. Bahasa merupakan bentuk permainan yang rumit yang melibatkan benda dan pikiran. Manusia juga menggunakan metafora dalam berbahasa yang menjadi serangkaian permainan kata-kata. Selain bahasa, ada juga mitos yang menjadi bentuk permainan. Manusia primitif memperhitungkan realitas dunia melalui pendasaran llahiyah. Jadi, ada unsur permainan yang menjadi garis batas antara senda gurau dan keseriusan. Sebenarnya permainan berlawanan langsung dengan keseriusan karena dalam permainan ada unsur kesenangan dan ketidakseriusan. Bermain dalam konsep Huizinga posisinya berada di luar kebijaksanaan dan kebodohan dan berada segaris dengan kebenaran dan kepalsuan, kecantikan dan keburukan. Tapi permainan harus terkait dengan nilai kebenaran atau kebaikan. Konsep permainan menyisakan perbedaan antara semua bentuk pemikiran yang lain sebagai tempat kita menstrukturkan mentalitas dan kehidupan sosial. Permainan yang dimainkan oleh kelompok atau komunitas akan cenderung mempertahankan kohesi kelompok walaupun permainan itu telah usai. Perasaan kebersamaan memainkan peran penting yang mengikat kohesi,solidaritas atau berbagi hal-hal yang penting. Bagi Huizinga, konsep bermain mencakup pula dimensi sosial manusia. Dalam permainan selalu terkandung unsur kebersamaan dengan orang lain, baik dalam kompetisi, kontes, tarian dan musik, turnamen dan lain sebagainya. Dari sini terlihat semua bentuk permainan adalah aktivitas sukarela (a voluntary activity). Bahkan dalam bentuk yang sangat bebas, sebuah permainan menentang proses alamiah. Manusia yang bermain digerakkan oleh kesenangannya akan permainan itu sehingga merasa bebas. Berbeda dengan anak-anak dan binatang yang bermain karena insting. Dari penjelasan di atas dapat disimpulkan bahwa, karakter utama dan pertama dari permainan adalah kebebasan. Karakter 
kedua dari permainan adalah aktivitas sementara, bukan kehidupan biasa atau kehidupan nyata. Dalam sebuah permainan selalu ada sifat pura-pura yaitu pura-pura serius dalam memainkan sesuatu padahal tujuannya hanya untuk kesenangan. Karakter ketiga adalah lokalitas dan durasi permainan yang berbeda dengan kehidupan biasa. Permainan selalu memiliki kesendirian dan keterbatasan sehingga makna dan kejadiannya selalu spesifik. Permainan selalu dimainkan sampai akhir dimana semua pergerakan, perubahan, asosiasi dan keterpisahan muncul dalam permainan itu. Tapi berbagai gerakan itu akan berhenti dengan tiba-tiba ketika permainan itu usai. Adapun hal yang paling penting dalam permainan adalah aturan, yaitu aturan yang akan mengikat permainan agar tidak keluar dari sistem permainan itu. Jika dilanggar maka permainan akan berhenti dengan sendirinya.

Berangkat dari konsep bermain dan permainan dari Huizinga maka dapat disimpulkan bahwa kaulinan oray-orayan termasuk pada bentuk permainan dan kegiatannya disebut bermain. Karena kaulinan barudak oray-orayan memiliki ciri-ciri yang sama dengan konsep bermain dan permainan dari Huizinga yaitu : bermain merupakan kegiatan yang dilakukan secara bebas dan sukarela, bermain bukanlah kehidupan biasa atau yang nyata, sehingga apabila kita amati secara seksama perilaku anak selama bermain, mereka berbuat pura-pura tidak sungguh-sungguh, bermain berbeda dengan kehidupan sehari-hari, terutama dalam tempat dan waktu, bermain selalu bermula dan berakhir, dan dilakukan dalam tempat tertentu, dan bermain memiliki tujuan yang terdapat dalam kegiatan itu, dan tidak berkaitan dengan perolehan atau keuntungan material.

Adapun bentuk lain dari kaulinan orayorayan ada di negara Cina yaitu Chase the Dragon's Tail yaitu permainan mengejar naga yang pengertiannya adalah naga merupakan binatang reptil besar yang ganas. Adapun prosedurnya adalah semua pemain masuk garis. Garis adalah naga. Setiap pemain memegang erat-erat ke pundak pemain di depan. Pertama, pemain sejalan, kepala, mencoba untuk menangkap pemain terakhir atau ekor. Semua orang mencoba menjaga kepala dari penangkapan ekor. Ketika kepala berhasil menangkap ekor, kepala keluar dan ekor menjadi kepala. Ketika semua orang keluar kecuali dua pemain, pertandingan dimulai lagi. Jika dilihat dari format dan aktivitasnya sangat menyerupai kaulinan oray-orayan yang dilakukan di kampung Cikondang.

Berdasarkan penjelasan di atas maka penulis menentukan fokus kajian dalam artikel ini adalah nilai-nilai pendidikan yang terkandung dalam kaulinan barudak Sunda yaitu oray-orayan yang merupakan bentuk permainan anak-anak yang hidup dan berkembang di Daerah Jawa Barat khususnya di Kampung Cikondang Desa Karanglayung Kecamatan Conggeang Kabupaten Sumedang. Dalam kaulinan orayorayan ini terdapat unsur-unsur permainan, nyanyian dan cerita. Hasil yang akan dibahas merupakan hasil studi lapangan terhadap konsep kaulinan oray-orayan, format kaulinan orayorayan dan aktivitas kaulinan oray-orayan pada masyarakat Kampung Cikondang, sehingga ditemukan makna, nilai, dan simbol-simbol yang terdapat di dalam lagu dan gerak kaulinan orayorayan. Kaulinan barudak yaitu oray-orayan diambil sebagai bahan kajian, karena penulis beranggapan kaulinan barudak oray-orayan mengandung berbagai nilai-nilai pendidikan yang dapat dikembangkan dalam pembelajaran di sekolah khususnya Sekolah Dasar dan di lingkungan keluarga.

Artikel secara khusus akan membahas mengenai konsep kaulinan oray-orayan, format kaulinan oray-orayan, aktifitas kaulinan orayorayan, makna (konsep, format dan aktifitas kaulinan oray-orayan), dan nilai pendidikan yang terkandung dalam kaulinan oray-orayan. 


\section{Kaulinan oOray-orayan pada Masyarakat Kampung Cikondang Kabupaten Sumedang Konsep Kaulinan Oray-orayan di Kampung Cikondang}

Oray-orayan merupakan kata berulang memakai akhiran-an yang artinya meniru atau menyerupai oray atau ular. Oray-orayan berasal dari kata "oray" bahasa sunda yang artinya "ular". Oray-orayan merupakan salah satu kaulinan urang lembur yang dimainkan secara berkelompok oleh beberapa anak perempuan maupun lelaki (7-20 anak) di lapangan terbuka ataupun dihalaman rumah. Untuk memainkannya biasanya anak-anak sambil bernyanyi lagu "orayorayan".

\section{Format Kaulinan Oray-orayan di Kampung Cikondang}

Bentuk kaulinan oray-orayan di Kampung Cikondang adalah sebagai berikut, permainan ini dapat dimainkan oleh anak laki-laki dan perempuan atau campuran yang berumur antara 5 sampai 12 tahun. Pada umumnya masih dikenal terutama dipedesaan, dilakukan di halaman sekolah maupun halaman rumah yang agak luas. Permainan ini dilaksanakan pada pagi hari, siang atau sore hari, maupun pada malam hari ketika bulan purnama. Jumlah pemain 7 sampai 20 anak, atau lebih banyak lebih baik karena akan lebih indah kelihatannya bagaikan ular yang sebenarnya. Permainan oray-orayan ini tidak memerlukan alat bantu, hanya memakai syair-syair lagu dan dalam budaya Sunda disebut kakawihan yang berisi tanya jawab yang dilakukan sendiri oleh mereka yang bermain.

\section{Aktivitas Kaulinan Oray-orayan di Kampung Cikondang}

Aktivitas permainan oray-orayan yang dilaksanakan di Kampung Cikondang dengan cara membuat barisan yang berjejer ke belakang, paling depan menjadi kepala ular, sedangkan di tengah dan belakang menjadi bagian tubuh dan ekornya dan ada dua orang anak yang menjaga dengan cara menempelkan tangannya dan diangkat keatas sehingga membentuk seperti terowongan yang harus dilewati ular. Agar terlihat seperti ular, setiap pemain meletakkan tangannya dipundak temannya yang berada di muka, kecuali yang menjadi kepala ular. Mulailah barisan atau ular itu berjalan meleok-leok mengikuti kepala ular seolah akan menerkam.

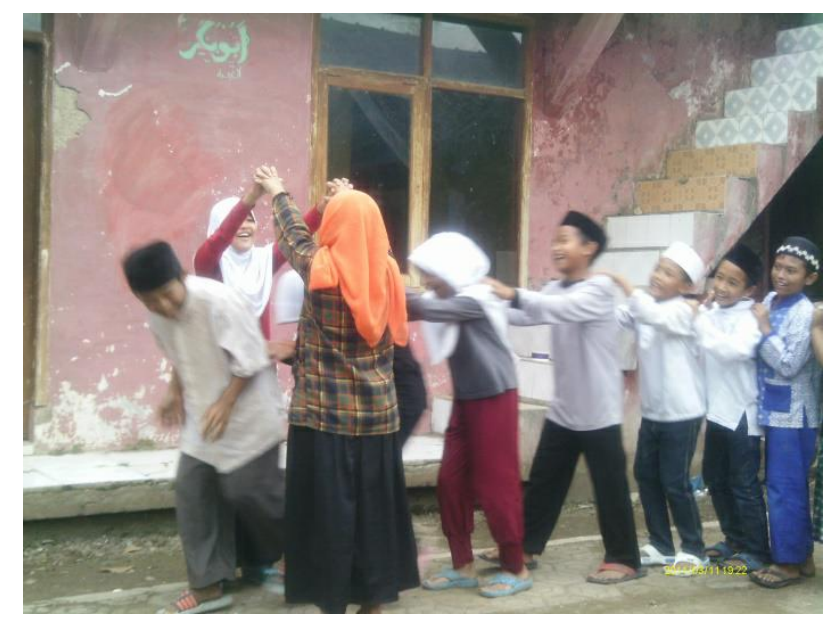

Setelah kakawihannya selesai maka ada satu anak yang tertangkap dan harus memilih mau ikut ke penjaga kanan atau kiri. Hal itu berlangsung sesukanya. 


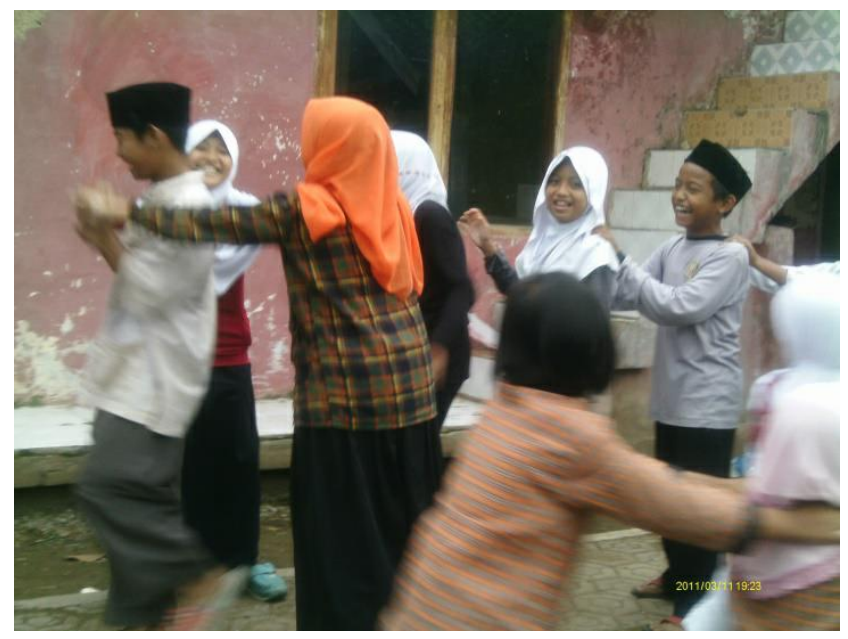

Dalam kaulinan oray-orayan ada kakawihan yang biasa anak-anak yang sedang bermain oray-orayan nyanyikan. Adapun kakawihan oray-orayan yang biasa anak-anak kampung Cikondang nyanyikan ketika melaksanakan kaulinan barudak oray-orayan adalah sebagai berikut :

Oray-orayan luar leor mapay sawah.

Entong ka sawah parena keur sedeng beukah.

Oray-orayan luar leor mapay kebon.

Entong ka kebon di kebon loba nu ngangon.

Mending ka leuwi di leuwi loba nu mandi

Saha anu mandi? Anu mandina pandeuri.

\section{Makna Kaulinan Oray-orayan}

Dengan teknologi informasi yang begitu mengglobal sekarang ini, kita sebagai pendidik tidak bisa berbuat banyak. Salah satunya yang dirasakan sangat terpuruk adalah dunia anakanak (telah lama para orang tua, pendidik serta mereka pemerhati dunia anak-anak melontarkan keprihatinan bahwa anak-anak sedang kehilangan dunianya). Untuk mengembalikan dunia anak yang hilang tersebut pendidik dapat menghidupkan kembali melalui kegiatan kaulinan barudak oray-orayan yang merupakan permainan anak yang mengenalkan anak pada lingkungan alam, hewan, tumbuhan dan segenap ciptaan Tuhan yang bisa membangun interaksi antara sesama teman.

Berdasarkan hasil wawancara dengan sesepuh pemerhati budaya asal Sumedang pada tanggal 26 Februari 2015 yaitu Bapa Odi, beliau adalah salah satu sesepuh Yayasan Sebelas April Sumedang, usia belaiu sekitar 85 tahun, tetapi beliau masih aktif mengajar di STKIP sebelas April Sumedang pada Prodi Pendidikan Basa Sunda, bapak Odi menjelaskan bahwa tidak ada yang tahu pasti tentang awal mula adanya kaulinan oray-orayan, kaulinan ini terjadi karena pengaruh kehidupan orang Sumedang sendiri, pada zaman dahulu hampir $90 \%$ adalah petani. Awalnya, permainan ini dimaksudkan hanya sebagai sarana hiburan atau permainan anak-anak, sepulangnya dari sekolah ataupun ketika mau mengaji. Dan permainan ini juga berasal dari kebiasaan bermain anak-anak zaman dahulu (sesuai dengan letak geografis yaitu pesawahan atau daerah pegunungan, ketika anak-anak bermain dan melewati pematang sawah yang padinya sedang menguning mereka harus disiplin dan berjalan berurutan (satu-satu) seperti barisan. Lalu diaplikasikanlah hal tersebut dalam kaulinan oray-orayan. Kaulinan oray-orayan ini dimaksudkan sebagai sarana rekreasi bagi anakanak yang hidup di pedesaan. Jadi pada waktu dulu, anak-anak pulang sekolah atau pulang dari sawah itu bermain dengan teman-temannya di sebuah lapangan atau lahan kosong untuk 
bermain kaulinan yang salah satunya kaulinan oray-orayan. Menurut Bapak Odi, dalam kaulinan oray-orayan itu menggunakan kakawihan untuk mengiringi gerakan-gerakan yang meliuk-liuk seperti ular.

Untuk memperjelas penjelasan Bapak Odi di atas, penulis mengutip pendapat Huizinga (1949) yang menjelaskan bahwa,

"Play is older than culture, for culture, however inadequately defined, always presupposes human society, and animals have not waited for man to teach them their playing. We can safely assert,even, that human civilization has added no essential feature to the general idea of play".

Dari pendapat Huizinga di atas dapat dijelaskan bahwa bermain lebih tua dari budaya, berarti bermain itu telah ada sebelum adanya budaya. Untuk budaya sendiri tidak cukup apabila didefinisikan, definisinya selalu mengandaikan masyarakat manusia. Huizinga dengan aman menegaskan bahwa, peradaban manusia telah memberi masukan bahwa adanya fitur penting untuk gambaran umum tentang bermain. Kalau kita kaitkan antara pendapat dari Huizinga dengan lahirnya kaulinan barudak orayorayan terdapat kemungkinan kaulinan orayorayan ini muncul sebelum lahirnya budaya Sunda.

Terkait hal di atas Kang Zae (Zaini Alif) pada Seminar Nasional PAUD UPI Cibiru 10 Maret 2014 tentang Permainan Tradisional dan Pendidikan Karakter, menjelaskan kapan bermain dan permainan dikenal oleh anak, dan penjelasannya sebagai berikut:

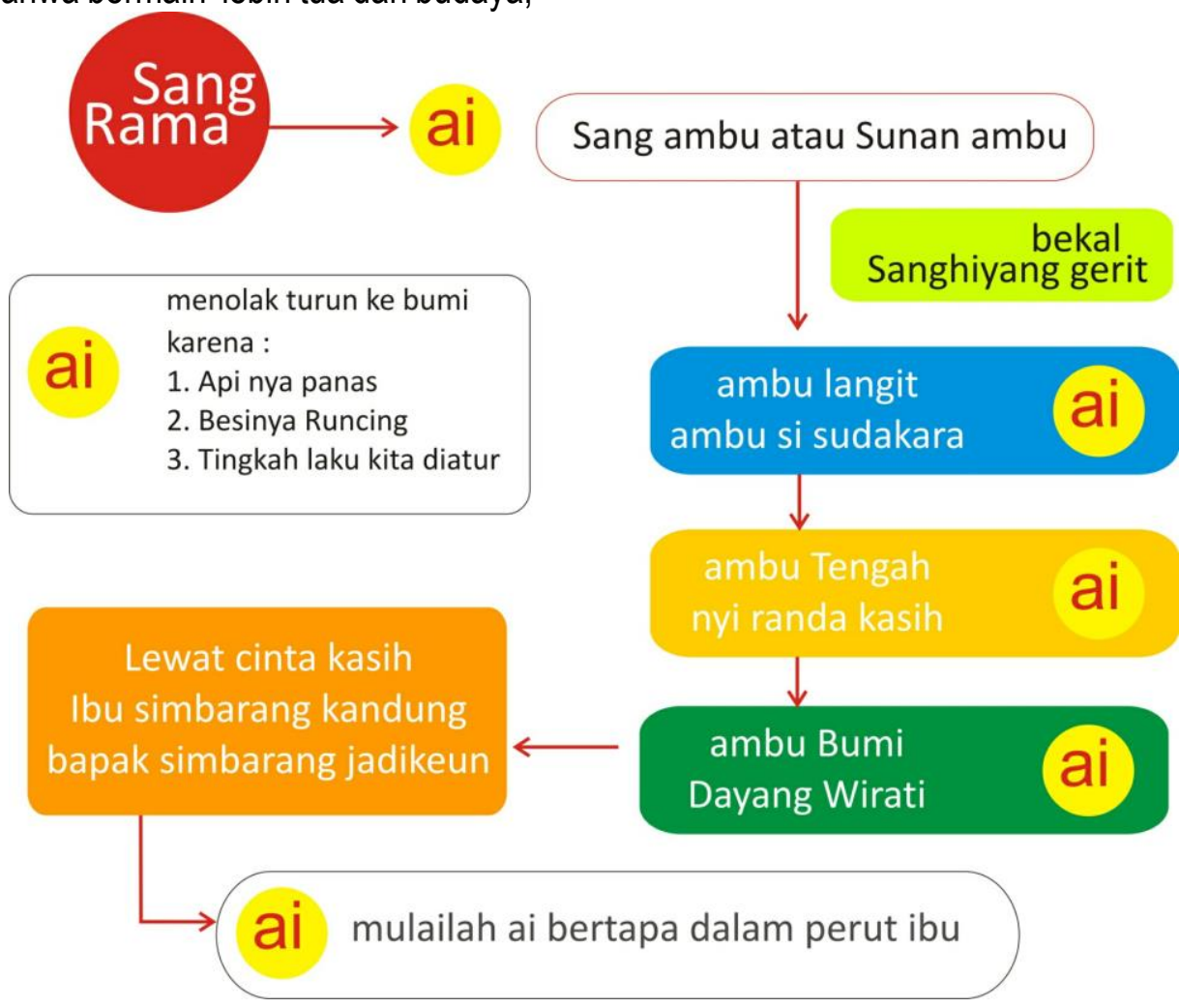




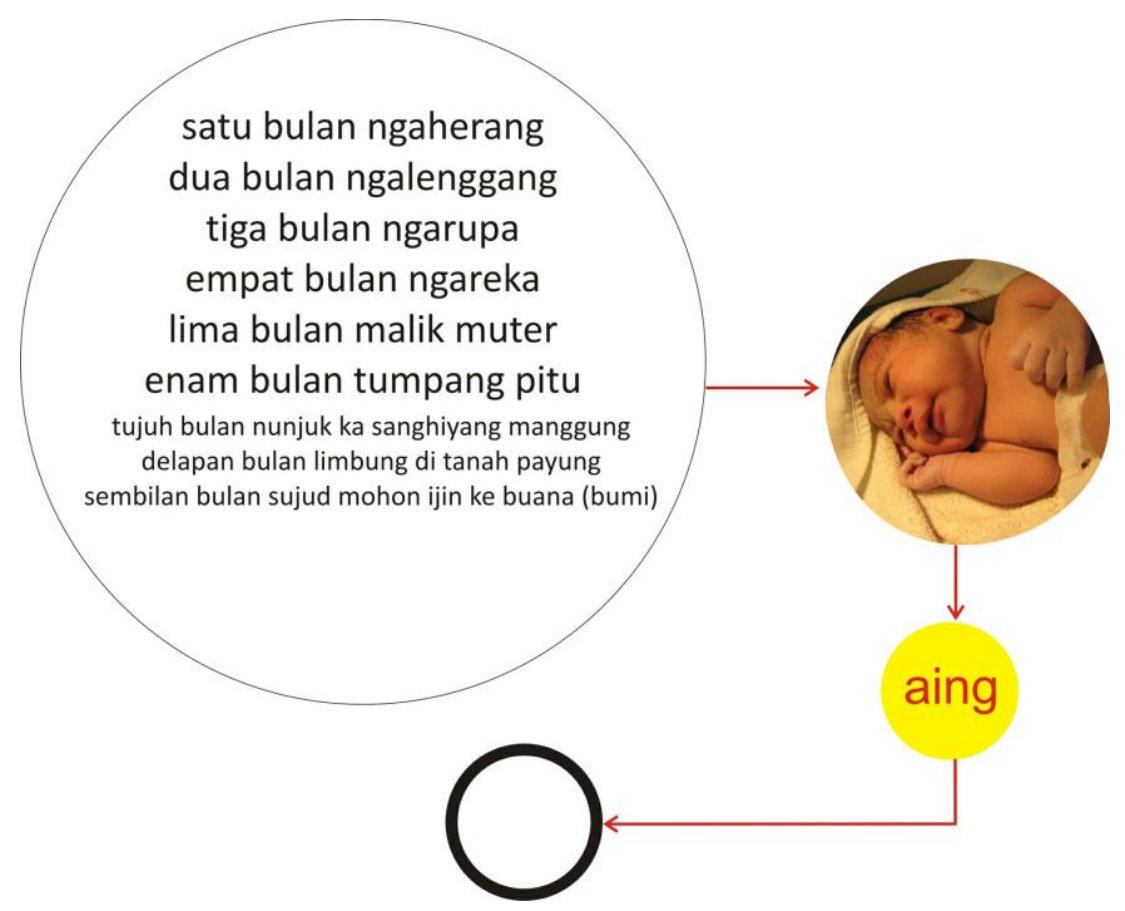

(Zaini Alif, 2013)

Dari bagan di atas dapat dijelaskan bahwa ai adalah cikal bakal manusia sebelum menjadi aing yaitu bayi yang melalui berbagai tahapan. Sang Rama dimaknai sebagai Yang Maha Kuasa. Dan setelah lahir ke dunia seorang anak langsung dikenalkan dengan bermain yaitu yang paling awal permainan sur ser. Dari penjelasan di atas dapat dimaknai bahwa bermain dikenal anak semenjak baru lahir.

Manusia berkembang melalui partisipasi dan berubah dalam kegiatan sosial budaya masyarakat mereka. Selaras dengan pendapat Vygotsky yang menyatakan bahwa pada masa kanak-kanak awal (early childhood) bahasa mulai digunakan sebagai alat yang membantu anak untuk merancang aktivitas dan memecahkan problem. Vygotsky juga menyatakan bahwa kemampuan kognitif berasal dari hubungan social dan kultur. Vygotsky mengatakan bahwa perkembangan anak tidak bisa dipisahkan dari kegiatan social dan cultural. Vygotsky menawarkan suatu potret perkembangan manusia sebagai sesuatu yang tidak terpisahkan dari kegiatan-kegiatan sosial dan budaya.
Vygotsky menekankan bagaimana prosesproses perkembangan mental seperti ingatan, perhatian, dan penalaran melibatkan pembelajaran menggunakan temuan-temuan masyarakat seperti bahasa, sistem matematika, dan alat-alat ingatan. la juga menekankan bagaimana anak-anak dibantu berkembang dengan bimbingan dari orang-orang yang sudah terampil di dalam bidang-bidang tersebut. Penekanan Vygotsky pada peran kebudayaan dan masyarakat di dalam perkembangan kognitif. Perspektif sosiokultural merupakan kultur teman sebaya (peer culture) jadi anak sebagai aktor budaya yang aktif dan kreatif, anak sebagai pencipta budaya (games with rules, social play) (Musthafa, 2014).

Selaras dengan pendapat Vygotsky, Piaget (1962) menjelaskan tahapan bermain lebih spesifik. Dari penjelasannya dapat disimpulkan bahwa tahapan bermain menurut dimensi kognitif adalah sebagai benikut : bermain praktis, yaitu saat anak mengeksplorasi semua kemungkinan suatu materi. Bermain 
simbolik, yaitu saat anak mulai menggunakan makna simbolik benda-benda. Bermain dengan aturan, yaitu saat anak mulai bermain dengan menggunakan aturan. Pernyataan ini selaras dengan konsep Huizinga tentang bermain dan permainan yang selalu terkandung unsur kebersamaan dengan orang lain, baik dalam kompetisi, kontes, tarian dan musik, turnamen dan lain sebagainya. Dari sini terlihat semua bentuk permainan adalah aktivitas sukarela (a voluntary activity). Bahkan dalam bentuk yang sangat bebas, sebuah permainan menentang proses alamiah. Manusia yang bermain digerakkan oleh kesenangannya akan permainan itu sehingga merasa bebas. Berbeda dengan anak-anak dan binatang yang bermain karena insting. Dari penjelasan di atas dapat disimpulkan bahwa, karakter utama dan pertama dari permainan adalah kebebasan. Karakter kedua dari permainan adalah aktivitas sementara, bukan kehidupan biasa atau kehidupan nyata. Dalam sebuah permainan selalu ada sifat purapura yaitu pura-pura serius dalam memainkan sesuatu padahal tujuannya hanya untuk kesenangan. Karakter ketiga adalah lokalitas dan durasi permainan yang berbeda dengan kehidupan biasa. Permainan selalu memiliki kesendirian dan keterbatasan sehingga makna dan kejadiannya selalu spesifik. Permainan selalu dimainkan sampai akhir dimana semua pergerakan, perubahan, asosiasi dan keterpisahan muncul dalam permainan itu. Tapi berbagai gerakan itu akan berhenti dengan tibatiba ketika permainan itu usai. Adapun hal yang paling penting dalam permainan adalah aturan, yaitu aturan yang akan mengikat permainan agar tidak keluar dari sistem permainan itu. Jika dilanggar maka permainan akan berhenti dengan sendirinya. Dan kaulinan barudak oray-orayan yang dilaksanakan di Kampung Cikondang bentuk dan aturannya sesuai dengan penjelasan di atas.

Telah banyak penelitian yang dilakukan terkait dengan manfaat permainan dalam dunia pendidikan salah satunya adalah Christie (2008) dalam artikelnya "Standards, Science, and the
Role of Play in Early Literacy Education" menyatakan bahwa bermain sedang dimasukan dalam program anak usia dini dalam mendukung bentuk yang langsung untuk mengembangkan melek huruf awal dan keterampilan berhitung. Jerome Bruner (1972) dalam Christie (2008) mengemukakan bahwa bermain adalah 'titik tolak' yang diperlukan untuk mempelajari caracara simbolik budaya, yaitu, bahasa, dan bermain yang memberikan kontribusi untuk kemampuan anak dengan meningkatkan pilihan perilaku mereka. Anak-anak yang imajinatif dalam permainan mereka lebih terbuka untuk sistem agar dapat mempengaruhi mereka dan dengan demikian mampu mengembangkan berbagai pengetahuan.

Roskos (2009) dalam artikelnya "Play's Potential in Early Literacy Development" menyatakan bahwa proses bermain merupakan sambungan kognitif kritis antara bermain dan keaksaraan berakar pada premis teoritis bahwa kemampuan representasional diperoleh dalam transformasi berpura-pura yaitu transfer ke bentuk simbolik seperti bahasa tertulis. Adapun hasil wawancara dengan Kepala TK Lab School UPI Cibiru (18/02/2015) bahwa permainan tradisional sudah masuk dalam kurikulum pembelajarannya dalam dua tahun ini yaitu setiap hari Kamis seluruh jam pembelajaran diisi dengan kegiatan permainan tradisional atau yang disebut kaulinan barudak salah satunya yaitu oray-orayan. Dan dengan adanya program tersebut guru-guru dapat melihat bahwa perkembangan anak berkembang cukup pesat dibandingkan sebelum menerapkan program pembelajaran.

Berdasarkan hasil wawancara dengan beberapa orang anak yang pernah melaksanakan kaulinan barudak oray-orayan pada hari Jum'at tanggal 24 April 2015 dapat penulis simpulkan bahwa : anak merasa senang dan gembira ketika melakukan kaulinan orayorayan karena dapat berekspresi secara bebas, mereka juga menjelaskan bahwa dengan kaulinan oray-orayan ini menjadi tahu kosakata baru, contohnya menjadi tahu kata "oray" artinya 
sama dengan ular, luar-leor artinya meliukmeliuk, leuwi artinya sungai. Anak-anak yang bermain kaulinan oray-orayan merasa lebih dekat dengan teman-temannya atau terjadi interaksi sosial yang sangat baik di alam bebas (bermain outdoor), dengan demikian anak merasa senang dan puas karena dapat bermain di alam bebas seperti di lapangan atau di halaman rumah yang luas. Mereka merasa tidak mau berhenti memainkan kaulinan oray-orayan (terkecuali bila kelelahan). Mereka mengungkapkan bahwa ketika bermain kaulinan oray-orayan mereka mendapatkan kepuasan tersendiri dalam artian mereka bisa bermain bersama dengan teman-temannya, bisa bernyanyi (ngawih) dan bisa bermain di alam bebas melalui kaulinan barudak.

\section{Nilai-nilai Kaulinan Oray-orayan}

Berdasarkan kajian di atas dapat dikaji bahwa nilai kearifan lokal yang terkandung dalam kaulinan oray-orayan, yaitu:

1. Nilai Seni, yaitu :

a. Nilai estetika gerak: barisan atau formasi yang membentuk ular "liakliuk" mengandung nilai keindahan tersendiri jika orang melihatnya. Barisan diatur menurut ketinggian agar satu sama lain agar pertahanan kuat dan satu sama lain dapat melindungi.

b. Nilai estetika sastra: pada lirik lagu membentuk sebuah rima (bunyi vokal lagu pada baris terakhir dalam sebuah baris pada bait lagu).

Contohnya : oray-orayan luar leor mapay saw[ah] - tong kasawah parena keur sedeng beuk[ah]

2. Nilai Pendidikan, yaitu:

a. Nilai kognitif : melatih teknik/strategi serta daya kreativitas anak.

b. Nilai moral/afektif: pada kaulinan oray-orayan ini, anak-anak tidak hanya memperoleh kesenangan tetapi juga belajar untuk melatih keterampilan berkelompok, kekompakan (kerja sama), memimpin, bertanggung jawab, melindungi dan mendukung.

c. Nilai Psikomotor: kaulinan orayorayan ini melatih kecekatan fisik motorik anak.

3. Nilai Filosofi: Dilihat dari kakawihan kaulinan oray-orayan ini memberi pesan kepada anak-anak agar tidak bermain di sembarang tempat, seperti yang disebutkan dalam lirik yakni sawah, jangan bermain di sawah ketika padinya sedang menguning karena kasihan petani takut panennya gagal, karena semua padinya rusak. Kemudian kebon, kata kebon dalam lirik lagu tersebut berarti kebun, jangan bermain di kebun karena ada tukang kebun yang sedang mengembala hewan, takut-takut mengganggu hewan gembalanya yan sedang makan. Ada leuwi, kata leuwi dalam lirik tersebut berarti sungai, anak-anak harus bermain di sungai karena banyak orang dewasa. Kakawihan barudak dalam kaulinan barudak oray-orayan menunjukkan ramalan mengenai sebuah gambaran atau situasi yang tidak dapat diketahui arah dan tujuannya, akan tetapi meminta korban (Uga, 1967).

Dede kosasih, dalam makalahnya "Etnopedagogi dalam Kaulinan dan Kakawihan Barudak Sunda" yang disampaikan pada "Konferensi Nasional dan Pembentukan Organisasi Profesi Pengajar Bahasa, Sastra dan Budaya Daerah Se-Indonesia" di Kaliurang Jogja menjelaskan bahwa dalam kaulinan oray-orayan terkandung nilai pemupukan sifat kebersamaan, sportifitas, kreativitas ataupun kecintaan terhadap alam dan lingkungan.

Salah satu cara untuk melestarikan kaulinan barudak oray-orayan ini dengan menyelenggarakan festival-festival mainan dan permainan tradisional atau kegiatan Festival Kaulinan Urang Lembur. Harus diselenggarakan workshop dan seminar yang membahas 
mengenai permainan tradisional Jawa Barat, yang melibatkan guru/calon guru siswa-siswa sekolah yang ada di sekitar Jawa Barat. Artikel ini juga mengkaji bagaimana cara mewariskan nilainilai yang terkandung dalan kaulinan oray-orayan agar dapat diaplikasikan dalam pembelajaran di Sekolah Dasar ataupun di lingkungan keluarga. Salah satunya adalah dengan cara memanfaatkan keterbukaan informasi dan komunikasi, salah satu contohnya dengan mempublikasikan hasil-hasil penelitian yang berkaitan dengan kaulinan barudak oray-orayan. Guru dapat menyisipkan nilai-nilai yang terkandung dalam kaulinan barudak (orayorayan) dalam pembelajaran sehari-hari di kelas, misalnya nilai kerja sama bisa kita aplikasikan dalam bentuk pembelajaran berkelompok. Kita bisa mengajarkan dan mengenalkan kaulinan barudak oray-orayan beserta nilai-nilai yang terkandung didalamnya kepada anak didik, anakanak yang berada di lingkungan sekitar.

\section{Nilai Pedagogik}

$\begin{array}{rrr}\text { Pendidikan dapat diartikan } & \text { sebagai } \\ \text { semua proses pembelajaran yang }\end{array}$ memungkinkan seseorang untuk memperoleh keterampilan, perilaku, pengetahuan, nilai-nilai dan norma-norma. Terkait dengan kaulinan orayorayan maka dapat disimpulkan bahwa nilai pendidikan yang dapat diambil dari fungsi-fungsi yang paling menonjol adalah fungsi pedagogis yang mendidik seorang anak menjadi orang yang berjiwa sportif. Misalnya permainan bertanding yang bersifat siasat berfungsi untuk mengembangkan daya berpikir, atau yang bersifat keterampilan fisik berfungsi mengembangkan kecekatan gerakan otot-otot (saraf motorik). Fungsi lainnya yakni fungsi rekreatif, sehingga dapat pula menjadi semacam pelipur lara, atau untuk melepaskan diri dari segala ketegangan perasaan, sehingga dapat memperoleh kedamaian jiwa.

Dalam kaulinan oray-orayan sifatnya rekreatif sangat bertautan dengan kakawihan barudak. Antara kaulinan dan kakawihan itu merupakan dwitunggal. Kaulinan dan kakawihan barudak Sunda, ternyata memiliki kearifan lokal yang luar biasa yaitu mengandung hal-hal positif, seperti pemupukan sifat kebersamaan, kreativitas ataupun kecintaan terhadap alam dan lingkungan. Permainan oray-orayan, misalnya, yang erat dengan kakawihan itu ternyata sarat dengan nilai-nilai kebersamaan karena dalam bermainnya harus melibatkan lebih dari lima orang. Meskipun jenis maupun bentuk kaulinan barudak oray-orayan sangat sederhana, tetapi secara tidak langsung mengandung makna yang sangat berguna terutama bagi pemupukan sikap mental anak-anak. Dengan jenis kaulinan barudak tersebut, anak-anak bisa menikmati kegembiraan hidup tanpa harus dibeli oleh nilai rupiah. Selain itu, tampak pula sikap kebersamaan dan rasa solidaritas anak-anak dalam bermain, hampir dapat dipastikan jauh lebih komunikatif satu sama lainnya.

Selaras dengan kajian teoritis dan penelitian-penelitian tentang bermain dan permainan yang telah dilakukan sebelumnya, maka kaulinan barudak oray-orayan ini dapat membantu perkembangan anak usia dini dalam mengembangkan seluruh aspek perkembangan anak dari mulai perkembangan bahasa, fisik motorik, seni, sosial emosional, kognitif dan moral.

\section{Kesimpulan}

Simpulan yang dapat diambil adalah sebagai berikut:

Kaulinan barudak oray-orayan adalah permainan anak (tradisi) yang mengenalkan anak pada lingkungan alam, hewan, tumbuhan dan segenap ciptaan Tuhan yang bisa membangun interaksi antara sesama teman.

Aturan main kaulinan oray-orayan ini adalah sebagai berikut permainan ini dapat dimainkan oleh anak laki-laki dan perempuan atau campuran yang berumur antara 5 sampai 12 tahun. Pada umumnya masih dikenal terutama dipedesaan, dilakukan di halaman sekolah maupun halaman rumah yang agak luas. Permainan ini dilaksanakan pada pagi hari, siang atau sore hari, maupun pada malam hari ketika 
bulan purnama. Jumlah pemain 7 sampai 20 anak, atau lebih banyak lebih baik karena akan lebih indah kelihatannya bagaikan ular yang sebenarnya. Permainan oray-orayan ini tidak memerlukan alat bantu, hanya memakai syairsyair lagu dan dalam budaya Sunda disebut kakawihan yang berisi tanya jawab yang dilakukan sendiri oleh mereka yang bermain.

Dalam kaulinan barudak oray-orayan terkandung nilai yaitu : pemupukan sifat kebersamaan, sportifitas, kreativitas ataupun kecintaan terhadap alam dan lingkungan. Kaulinan barudak oray-orayan juga memiliki fungsi pedagogis dan fungsi rekreatif.

Salah satu upaya untuk melestarikan kaulinan barudak oray-orayan ini adalah dengan menyelenggarakan festival-festival mainan dan permainan tradisional Jawa Barat atau kegiatan Festival Kaulinan Urang Lembur dan harus diselenggarakan workshop dan seminar yang membahas mengenai permainan tradisional Jawa Barat, yang melibatkan guru/calon guru siswa-siswa sekolah yang ada di sekitar Jawa Barat.

\section{Daftar Pustaka}

Alif, Zaini. (2014). Bahan Seminar Nasional PAUD. UPI Cibiru.

Alif,Zaini. (2014). Pendidikan Karakter dalam Mainan dan Permainan Tradisional Jawa Barat. Pemerintah Provinsi Jawa Barat.

Around Kids. World in Games: Games of the World: How to Make Them, How to Play Them, How They Came to Be by Frederic V. Grunfeld. Published by the Swiss Committee for UNICEF in 1982.

Budaya. Dalam: Yang Tersirat dan Tersurat. Fakultas Sastra: Universitas Indonesia.

Christie, James F. (2008). Standards, Science, and the Role of Play in Early Literacy Education. Arizona State University.

Creswell, John W. (2014). Research Design (Qualitative, Quantitative and Mixed Methods Approaces).Los Angeles : Sage.
Direktorat Permuseuman. (1998). Permainan Tradisional Indonesia.

Huizinga,J. (1949). Homo Ludens (A Study of The Play-Element in Culture). London.

Kosasih, Dede. Etnopedagogi dalam Kaulinan dan Kakawihan Barudak Sunda. Konferensi Nasional dan Pembentukan Organisasi Profesi Pengajar Bahasa, Sastra dan Budaya Daerah Se-Indonesia: Kaliurang Jogja.

Kosasih, Dede. (2013). Makalah Etnopedagogi dalam Kaulinan Barudak.

Majoni, Cuthbert \& L. Taurai. Integrating Traditional African Education into Current Educational Practices: Suggestions for Primary School Pedagogy. Chinyanganya, Zimbabwe Open University, Mashonaland Central Region P. Bag 984, Bindura, Zimbabwe. Mashonaland Central Region P. Bag 984, Bindura, Zimbabwe.

Musthafa, Bachrudin. (2014). Literasi Dini, Konsep, Teori dan Praktek. Bandung : CREST.

Nur Afianti, Laksmita. (2012). Kajian Struktur, Konteks Pertunjukkan dalam Kakawihan Kaulinan Barudak Lembur pada Masyarakat Sunda serta Model Kesehariannya. UPI : Respositori. UPI. Edu.

Piaget, Jean. (1962). Play, Dream and Imitation.

Primadi. (2000). Proses Kreasi, Apresiasi, Belajar. Bandung ; Penerbit ITB.

Roskos, Kathleen A. et.al. (2009). Play's

Potential in Early Literacy Development.

Arizona State University, USA.

Saputra, Suria.Uga.Seri III, Baranangsiang No. 4 Tahun 1967.

Sunaryo, Ayo . Internalisasi Nilai-nilai Tradisi pada Penciptaan Tari Anak Berbasis Budaya Lokal.

Vygotsky, L. (1978). The Role of Play in Development (pp. 92-104). In Mind in Society. (Trans.M. Cole). Cambridge, MA: Harvard University Press. 